\title{
建築用材ならびに防蟻処理材のしろありに よる食害の実験的研究
}

\section{1. 序}

しろありによる被害対象は、建築物は申すにおよばず 立木、木柱、枕木、坑木、家具、畳、書籍、衣類などの 植物䋊維構成物ならびに皮革製品、または等機質の電線 のケーブル用鉛管、最近では合成樹脂製の電線ケーブル 被覆材まで们よんでいる。建築物においては、単に木 造建築物のみにとぶまらず、コンクリートブロック造お よび鉄筋コンクリート造の木製の床組、造作材、建具材 にまで被害がみられている。

しろありによる食害は、その恐らしされおいて吾人は 認識するけれども气の被害の総量が正確に把握されない ためと、やま方方市方被害地域㭁いては、その被害 を腐朽と混同しているため、被害の実態を把めず警鐘を 打ち鳴らすまでにいたつていない。木材資源の合理化使 用、建築物の保全などの面からも、てれが防除は緊急老 要する仕事である。

しろあり防除の方法としては、防霍工法と同し上うに 構造法による方法、選材による方法、木材防ぎ剂処理に よる方法などが考えられる。構造法仙よる場合は、従来 の工法と異なつた特殊工法を採用するということで、選 材による方法法、その材の使用される簡所と力学的性質 と供給量などの相関関係などがあり、その実施は困難な 点が少なくない。

比較的簡単でしか子效果のある点では、木材防ぎ剂処 理化よる方法が最も採用され易い防ぎ工法である。木材 防ぎ剤処理工法のさいに問題となる点は、その薬剤の効 力を短時日に判明しようとする試験方法である。

防ぎ剂の效力試験方法については、松辽材粉末、滤紙、 ケント紙を使用した試験方法とその結果については、す

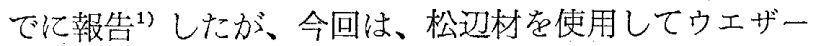
メーターにより耐候操作を行なつた試験結果と建築用材 の 25 樹種ならびに木質材料の耐ぎ性試験を行なつた試 験結果を報告する。

\section{2. 試験目的}

実験室においてしう方方を飼育し、適当な期間食害さ せて、建築用材ならびに木質材料の耐ぎ性の級別と防ぎ 剂の防ざ効力判定ならびに飼育法による防ぎ効力試験方 法の検討を行なう。

*早稲田大学教授 工博, **同 助手, ***関東学院大学助手

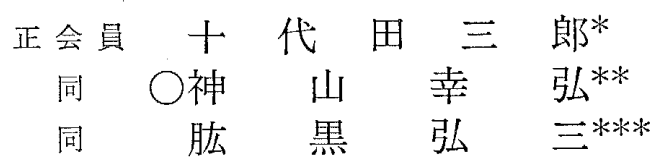

\section{3. 試験目的}

次に掲げるような武験項目について試験を行なつた。

i 建築用材の耐ぎ性試験

ii 木質材料の酎ぎ性試験

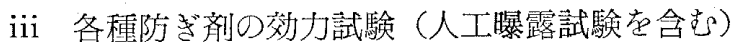

\section{4. 試験項目}

i 供試しろあり香川県直島町 海岸松林中の 切株飞営栄中のもの在、そのま〉堀起し東京に直送して 実験公において飼育したい方しう市方を用いた。各材の 食害試験にあたつては、一培養器中に約 300 匹のしろあ りを投入して食害させた。

ii 培餈基 容器汇は容量 $700 \mathrm{cc}$ の三角フラスコを 使用し、乾熱殺菌した総量 $400 \mathrm{~g}$ の豊浦標準砂を 2 等分 して、一方は $25 \%$ の蒸溜水を含浸させてフラスコの底 に敷きつめ、その上残りの $10 \%$ の蒸溜水を含浸させ た標準砂を乗せて軽く押して表面を平坦にしてしうあ门 の水分補給源とした。次に試験体在柾目面を下にして水 平比沶、計量したしらあり在投入して水分の乾燥を防 ぐためにフラスコ上部に棉柽学施した。

iii 試験体の種別１）建築用材の耐ぎ性試験には、 建築用材として常用されている日本産針葉樹のアカマッ 秋由スギ、ヒノキ、エゾマツ、地マツ、カヤ、モミ、ツ ガ、ヒバ、広葉樹のブナ、セン、ナラ、サクラ、ケヤキ カツラ、ホオ、シオシ、アカダモ、ニレ、クス、外国産 のチーク、ラワン、ベイスギ、ベイヒ、スブルースの辺 材を使用した。2) 木質材料としてパーティクルボード、 硬質䋖維板、合板の食害試験を行なつた。3）防ぎ剂の 効力試験には、アカマツ辺材を用意してれに処理を行な つt。

iv 試験体の寸法

建築用材 $20 \mathrm{~mm} \times 50 \mathrm{~mm} \times 5 \mathrm{~mm} \quad 1$ 樹種につき 6 個 木質材料，建築用材と同一寸法であるが厚さのみ製品 厚とした。各 5 個

防ざ処理木材 $20 \mathrm{~mm} \times 50 \mathrm{~mm} \times 5 \mathrm{~mm}$ 各 6 個 $\mathrm{v}$ 食害期間

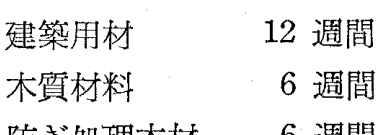

防ぎ処理木材 6 週間

vi，培養器維持条件 綿栓した三角フラスコを温度 25 
${ }^{\circ} \mathrm{C} \pm 2{ }^{\circ} \mathrm{C}$, 温度 $75 \% \pm 5 \%$ の恒温恒湿槽内に保存した。 vii 防ぎ薬剤の種類とその処理 防ぎ薬剂の種類は、 クレオソート油、P.C.P. $2 \%$, Na-P.C.P. $2 \%$, 水銀 B. H.C. 乳剂 $2 \%$, P.C.P. クロールデン乳剂 $2 \%$, JISK 1550 第 3 種 $3 \%$ の 薬剤とし、減圧法により減圧值 50 $\mathrm{mm}$ とし完全注入を行なつた。薬刜吸收量は、100\%土 $10 \%$ である。

耐候操作としては、ウエザーメーターを使用し、600 400，200，100 時間の紫外線照射岩行ない、また、1サ イクル 120 分、 12 分間の撒水友行なつた。 0 時間とし ては、室内風乾 2 ケのもの京使用し、いづれの試験体 とも $60^{\circ} \mathrm{C} 48$ 時間の乾燥范行ない全乾重量老測定した。

\section{5. 試験の結果とその考察}

しろありによる屋内食害試験は、しろあり周囲の環蕒 条件が自然繁殖条件と異なるためにその活力阻ぎ、な いしは自然条件下に打ける結果と相違した結果を生ずる ことがあるが、反面短時日にしかるも観察しながら結果が 得られるという利点もある。今回の実験も食害過程を観 察するために前述のような試験方法を採用した。

i 試験方法の決定 1) しろありの棲息には、温度、 湿度、水分が必要欠くべからざるものである。温度に関 しては、 $10^{\circ} \mathrm{C}$ 以上て行動か活溌になるといわれており、 夏季温度の平均として $25^{\circ} \mathrm{C}$ 在採用した。湿度に関して は、しろありの体表面そのもの力乾燥に対して弱いの で、環境規整を計る目的だけで恒温槽内の乾燥在防ぐた わ $75 \% \pm 5 \%$ とした。三角フラスコ内の湿度は、槽準 砂が含水しているので 75\% 上下となるととはない。水 分は、しろありの棲息にとつて必要欠くべからざるもの であるため標準砂に含浸させで水分を保持させた。2) 試験体の形状は、角型のものか開平のものより食害し易 く、食害量も多いように思われるが、しろあり食害過程 が観察できないので局平な形状とした。3）しろあり食 害は、しろありの数により幾何級数的な増加を示す傾向 があるため、採取したしろあり総数と試験内容を考慮し て300 匹とすることにした。4）食菁期間の決定は、新 たな試験方法を採用したので皆目見当がつかず、試験と 平行して試験体と同寸法のアカマツ辺材を用意して隔週 に一フラスコ（試験体３ケ）づつとりだし食害量を知ら べ、また観察によりダニ発生など交考慮して 12 週目と

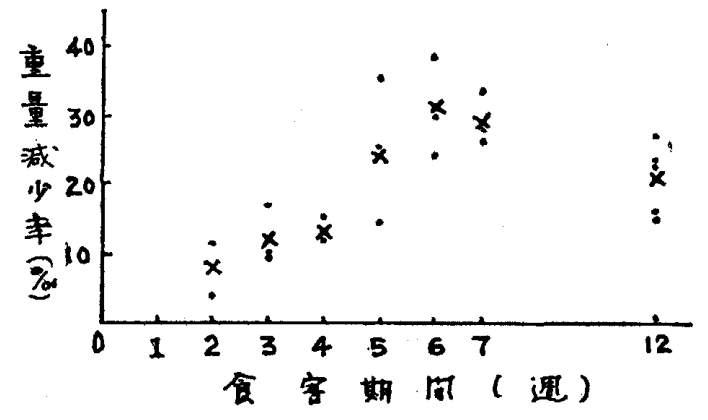

第 1 图 アカマツ辺材の週別食害
した。隔週にとりだした結果は、第1図に示したが、12 週食害させても6 週食害させたものに䄺よばない場合も ある。この原因は、挿入したしろありの活力の問題、材 の新鮮度いわゆる組成分の影響、環境条侏などが考慮さ れる。

\section{ii 实験過程}

試験樹種 25 , フラスコの数 50 個を 12 週観察すると 様々な変化がグルーブでとに起る。その代表的なもの は、1）4日目で全樹種の食害が初まつた。2）試験期間 中のしろありの動静は、300 匹の大部分九試験体の上部 で活動していたものと、フラスコの底部にもぐつてしま つてほとんど試験体上部には出てとないものとの2つに 分かれた。3）試験開始後 2〜4 日目位からフラスコの周 囲小いしは試験体に砂をかぶせる作業が開始されたが、 その種類を 3 つ分けるととができる。一つは、試験体 の周夙あるいは全面走砂で被覆してしまうもの、いま一 つは、フラスコの周团に砂奇がせ外界との遮断在計ろ うとするもの、他の一つは、フラスコに数条の蛾道をつ くり棉栓套食い破つて外界へでようとするものである。 4）12 週後にとりだした試験体の食害状沉は、a. 年輪 そ沿つて春材のみ食害、b. 長辽の端部にある春材を側 面より食害したもの、c. 試験体の上下表面から一様に 食害したもの、d. 木日より侵入し、春材部在穿孔して いくものなどあつた。一般に、年輸の鮮明なものは春材 部在、不鮮明なものにあつては表面を一䇐汇食珰されて いる。

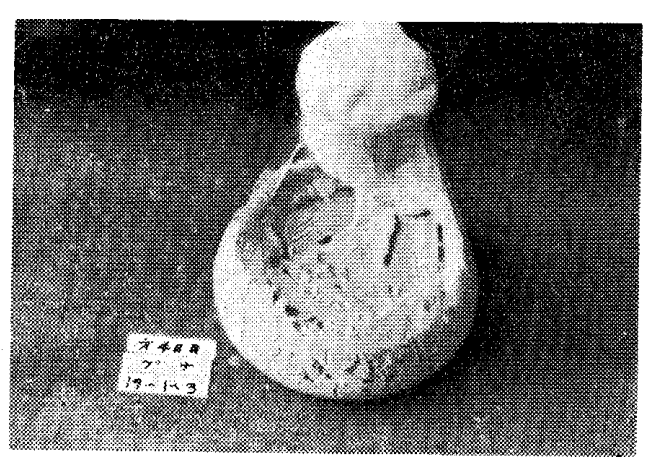

写真一1 偍篥状 況

合板は、主に $3 \mathrm{~mm}$ ある芯板か㴤面より食害后らけ、

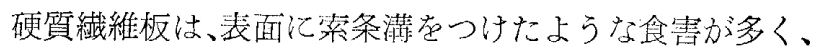
パーテイクルボードは、吸水により材が膨㳥してしまつ たので筑孔しで食㕩をうけている。

iii 建築用材ならびに木質材料の食害

食害試験の結果は、第 1 表のとおりである。涏来の調 查結果からいえば、木造建築物のい光しろむりにより食 害される樹種のうちではアカマツが小屋梁に便用されて いて被害が最も大きかつたが、今回の試験結果では必ず しもそれを裹付けていない。との理由は、試験体アカマ ツ材が比較的枯らされた材を使用してしまつたためと思 われる。 
第 1 表 建築用材のしろあり食害量（週 12 間）

\begin{tabular}{|c|c|c|c|c|c|c|c|}
\hline \multirow[t]{2}{*}{ 樹 } & \multirow[t]{2}{*}{ 種 } & \multirow{2}{*}{$\left|\begin{array}{ll}\text { 平 } & \text { 均 } \\
\text { 年輸巾 } \\
\mathrm{mm}\end{array}\right|$} & \multirow{2}{*}{$\begin{array}{l}\text { 平均全 } \\
\text { 乾比重 }\end{array}$} & \multirow{2}{*}{\multicolumn{2}{|c|}{ 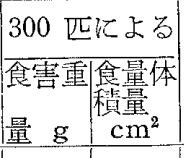 }} & \multirow{2}{*}{$\begin{array}{c}\text { 重量減少率 } \\
\text { 最小平均最大 }\end{array}$} & \multirow[t]{2}{*}{ 観 察 事 項 } \\
\hline & & & & & & & \\
\hline- & ク & 6.7 & 0.643 & 0.37 & 0.57 & $2.5 \sim 3.8 \sim 6.1$ & 取出時活動力小 \\
\hline セ & ע & 3.3 & 0.507 & 0.68 & 1.34 & $6.5 \sim 8.9 \sim 11.3$ & “ 活動中 \\
\hline$\ngtr$ & $\neq$ & 2.5 & 0.514 & 0.71 & 1.38 & $3.1 \sim 9.2 \sim 26.1$ & Aフラスコ死亡 \\
\hline ワ & Y & - & 0.545 & 1.02 & 1.87 & $8.4 \sim 12.5 \sim 16.2$ & " 活動力小 \\
\hline ナ & ラ & 2.2 & 0.562 & 1.18 & 2.09 & $8.8 \sim 14.0 \sim 23.4$ & Aフラスコ死亡 \\
\hline 力 & 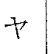 & 2.9 & 0.387 & 0.83 & 2.16 & $6.2 \sim 14.3 \sim 26.7$ & 取出時底部で活動 \\
\hline シオ オ & $\ddot{~}$ & 5.0 & 0.571 & 1.34 & 2.34 & $7.8 \sim 15.7 \sim 26.4$ & 取出時, 材内食害中 \\
\hline ブ & ナ & 2.9 & 0.667 & 1.79 & 2.65 & $10.6 \sim 17.9 \sim 27.7$ & Aフラスコ死亡 \\
\hline ホ & オ & 2.2 & 0.477 & 1.29 & 2.85 & $13.0 \sim 18.9 \sim 24.3$ & 取出時活動中 \\
\hline ッ & ガ & 1.7 & 0.477 & 1.38 & 2.90 & $10.2 \sim 19.3 \sim 40.3$ & 取出時底部で活動中 \\
\hline ク & ラ & - & 0.517 & 1.59 & 3.16 & $11.5 \sim 20.5 \sim 37.9$ & $\begin{array}{l}\text { A フラススダ二発生 } \\
\text { B注底部活動中 }\end{array}$ \\
\hline ベイ & ヒ & 1.5 & 0.433 & 1.34 & 3.10 & $7.5 \sim 20.7 \sim 28.2$ & 取出時材内食害中 \\
\hline アカマ & ッ & 1.8 & 0.595 & 1.91 & 3.36 & $15.2 \sim 21.4 \sim 27.8$ & $"$ \\
\hline ク & ス & - & 0.448 & 1.47 & 3.27 & $1.59 \sim 21.8 \sim 32.0$ & $"$ \\
\hline エゾマ & 叉 & 4.0 & 0.423 & 1.46 & 3.55 & $8.0 \sim 23.0 \sim 40.0$ & " \\
\hline 厂カダ & & 3.3 & 0.650 & 2.41 & 3.69 & $16.0 \sim 24.7 \sim 44.2$ & $"$ \\
\hline$\epsilon$ & $\Sigma$ & 4.0 & 0.367 & 1.47 & 4.02 & $15.0 \sim 26.7 \sim 40.0$ & $"$ \\
\hline 地 マ & ツ & 6.7 & 0.402 & 1.62 & 4.02 & $9.5 \sim 26.9 \sim 47.2$ & $"$ \\
\hline スプルー & & 2.5 & 0.377 & 1.53 & 4.04 & $16.9 \sim 27.0 \sim 35.5$ & " \\
\hline$=$ & $v$ & 2.9 & 0.476 & 1.97 & 4.13 & $15.4 \sim 27.6 \sim 37.9$ & " \\
\hline カ ッ & ラ & - & 0.415 & 1.96 & 4.72 & $25.0 \sim 31.5 \sim 39.1$ & 取出時底部で活動中 \\
\hline 秋田大 & ギ & 5.0 & 0.296 & 1.42 & 4.82 & $22.2 \sim 32.0 \sim 46.7$ & 取出時材内食害中 \\
\hline 七 & f & 2.0 & 0.372 & 1.99 & 5.22 & $14.9 \sim 34.7 \sim 45.4$ & " \\
\hline ヒ & ミ & 3.3 & 0.321 & 1.85 & 5.74 & $33.1 \sim 38.3 \sim 48.5$ & 取出時底部で活動中 \\
\hline ヘイス & & 1.8 & 0.314 & 1.81 & 5.89 & $18.9 \sim 39.3 \sim 53.1$ & 取出時材内食害中 \\
\hline
\end{tabular}

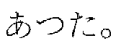

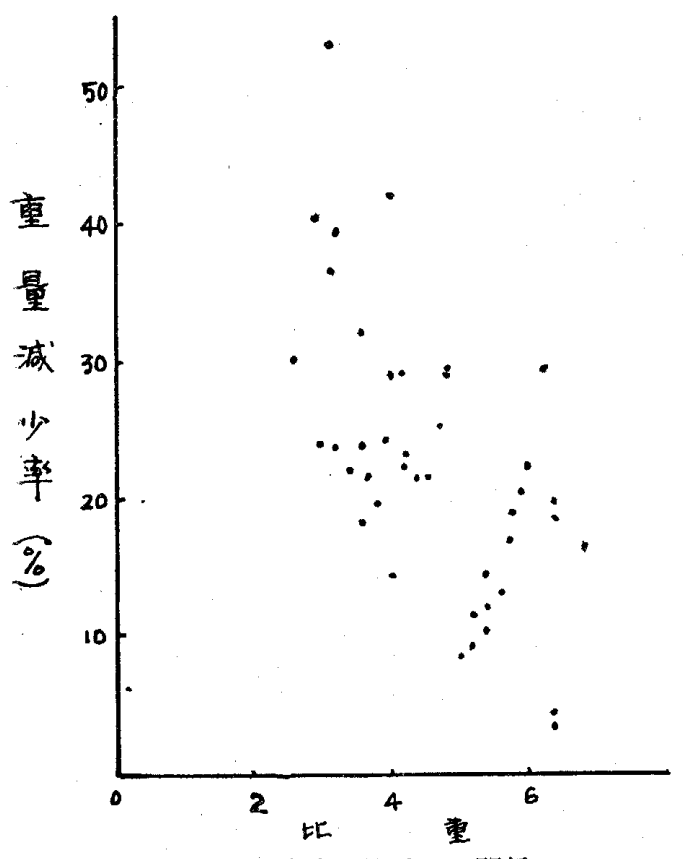

第 2 図食害と比重との関係

1）比重と食害との関係

しろありによる食害は、臂朽菌が酵素をだしてセル口 一ズを分解させるのとは異なり、牙でもつて木材を侵食 するため明らかに物理的損傷である。物理的損傷ならば 当然その比重とか硬さが、その樹種の食害の尺度とな る。第 2 図名沶すように比重と重量隇少率との関係は、
一般に比重の増加に伴なつて重量減少率 が少くなくなつている。第1表でもわか るごとくアカマツ、アカタモ、ブナなど は、比重の大きい割俍食害し易いことが わかる。硬さについては測定を行なわな かつたが、硬さそのものが比重と比例関 係にあるので比重の場合と同様な維果が 光られると思う。

\section{2) 組成分との関係}

しろありは、木材中のセルローズ、へ ミセルローズを食䬲とするが、今回の結 果では、セルローズ量と食害量との間に は何等相関関係がなかつた。むろ比重 が大きく食害量も大きからたアカマツ、 アガタモ、ブナなどの組成分のある種の

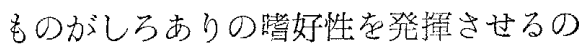
ではないかと思われる。

\section{iii 木質材料の食害について}

木質材料とい兄ども植物質繊維素で構 成されている以上食害は免がれず、その 結果第 2 表のとおりである。防资処理し たパーテイグルボードに岕つては、防炎 鼡方防ぎ郊力のあるせい汃、無処理の 3 倍の抵抗性があつた。3者のふかでは、 比重の大きな硬質瀻維板の被害が最小で
第 2 表 木質材料のしろあり食害量（6週間）

\begin{tabular}{|c|c|c|c|}
\hline & 全執比重 & $\begin{array}{l}200 \text { 殴に5る } \\
\text { 含有重量 } \mathrm{g}\end{array}$ & 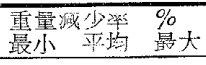 \\
\hline 硬 質 縕 維 板 & 0.94 & 0.11 & $2.3 \sim 3.5 \sim 4.4$ \\
\hline " 難燃処理 & 0.99 & 0.09 & $2.8 \sim 3.2 \sim 3.7$ \\
\hline 板 & 0.54 & 0.08 & $3.9 \sim 5.4 \sim 5.8$ \\
\hline " 難燃処理 & 0.59 & 0.11 & $4.6 \sim 5.3 \sim 5.8$ \\
\hline パーティクルボード & 0.63 & 1.25 & $30.1 \sim 36.4 \sim 47.5$ \\
\hline " 難燃処理 & 0.60 & 0.39 & $8.4 \sim 9.8 \sim 12.0$ \\
\hline
\end{tabular}

iv 防ぎ阂の效果について

試験の結果は第 3 表に示しているが、その結果は各種 防ぎ成の性格を表わしているといつてよい。試験結果は 薬剂処理による重量、体積の変化荧考慮して観察による こととした。一つは、試験体の食害状態であり、他の一 つはしろありの死亡確認である。防式用の效力としては 呼败毒、接触毒、食中毒、忌避効力作用などあるが、今 回の試験結果からは、クレオソート油は呱吸表、忌避効 力作用方、 P.C.P. 飞は忌滓効力が、B.H.C. 水銀ク口 ルデンには接触毒、呼吸毒作用が、JIS K 1550 第 3 種 の薬剤には食中毒作用があるここがわかる。

クレオソート油処理材は 600 時間の耐候操作後もその 材は食害法うけていない。しかし、200 時間以後の楸候 操作以後注呼吸毒作用が消減してしまい、僅かに忌避效 力か残留しているにとづまる。接触させたしろありは、 
第 3.表 防ぎ剂の効力試験 試験体 3 ケ

\begin{tabular}{|c|c|c|c|c|c|c|}
\hline \multirow{2}{*}{ 防ぎ剂の種類 } & \multirow{2}{*}{ 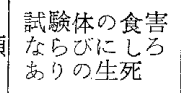 } & \multicolumn{2}{|c|}{ 耐 候 } & 操 & \multicolumn{2}{|c|}{ 作 $\mathrm{hr}$} \\
\hline & & 0 & 100 & 2,00 & 400 & 600 \\
\hline 油レオンート & 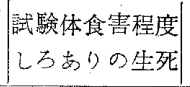 & $\begin{array}{c}0 \\
6 \text { 昌目 } \\
\text { 死亡 }\end{array}$ & $\begin{array}{c}0 \\
6 \stackrel{\text { 日目 }}{ } \\
\text { 死亡 }\end{array}$ & $\begin{array}{c}0 \\
\text { 生存 }\end{array}$ & $\begin{array}{c}0 \\
\text { 生存 }\end{array}$ & $\begin{array}{c}0 \\
\text { 生存 }\end{array}$ \\
\hline P. C. P. & 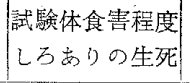 & $\begin{array}{c}0 \\
\text { 生存 }\end{array}$ & $\begin{array}{c}0 \\
\text { 生存 }\end{array}$ & $\begin{array}{c}0 \\
\text { 生存 }\end{array}$ & $\begin{array}{c}3 \\
\text { 生存 }\end{array}$ & $\begin{array}{c}3 \\
\text { 生存 }\end{array}$ \\
\hline Na-P.C.P. & 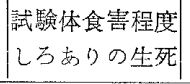 & $\begin{array}{c}0 \\
\text { 生存 }\end{array}$ & $\begin{array}{c}0 \\
\text { 生存 }\end{array}$ & $\begin{array}{c}2 \\
\text { 生存 }\end{array}$ & $\begin{array}{c}3 \\
\text { 生存 }\end{array}$ & $\begin{array}{c}3 \\
\text { 生存 }\end{array}$ \\
\hline B.H.C.- 水銅 & 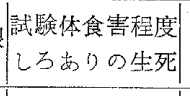 & \begin{tabular}{|c}
0 \\
$4 \stackrel{\text { 日目 }}{ }$ \\
死亡 \\
\end{tabular} & $\begin{array}{c}0 \\
7 \stackrel{\text { 日日 }}{ } \\
\text { 死亡 }\end{array}$ & \begin{tabular}{|c}
1 \\
7 日目 \\
死亡
\end{tabular} & $\begin{array}{c}0 \\
6 \text { 昌目 } \\
\text { 死亡 }\end{array}$ & $\begin{array}{c}4 \\
6 \text { 昌目 } \\
\text { 死亡 } \\
\end{array}$ \\
\hline Cr-P.C.P. & 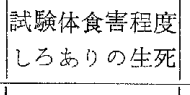 & $\begin{array}{c}0 \\
14 \text { 日目 } \\
\text { 死亡 } \\
\end{array}$ & $\begin{array}{c}0 \\
14 \text { 日目 } \\
\end{array}$ & $\begin{array}{c}0 \\
21 \text { 日目 } \\
\text { 死亡 }\end{array}$ & $\begin{array}{c}0 \\
21 \text { 目 } \\
\text { 死亡 }\end{array}$ & $\begin{array}{c}0 \\
21 \text { 目 } \\
\text { 死亡 } \\
\end{array}$ \\
\hline $\begin{array}{c}\text { JIS-K } 1550 \\
\text { 第3 耗 }\end{array}$ & 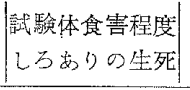 & $\begin{array}{c}0 \\
- \\
\end{array}$ & $\begin{array}{l}0 \\
-\end{array}$ & 一部死 $^{1}$ & \begin{tabular}{|c|}
3 \\
生存
\end{tabular} & $\begin{array}{c}2 \\
\text { 生存 }\end{array}$ \\
\hline 食害程度 & 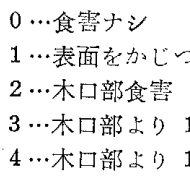 & $\begin{array}{l}\text { Dr程度 } \\
1 / 4 \text { 辺長 } \\
1 / 2 \text { 辺長 }\end{array}$ & & & & \\
\hline
\end{tabular}

死亡するととなくフラスコ底部えと移動してしまう。

P.C.P. 処理材は、処理当初は忌擗效力があるが、溶 剤型にあつては 400 時間以後、水溶性にあつては 200 時 間以後食害をうけていた。雨露に曝され易い場合には、 水溶性のものは邀け、油溶性のもの在採用したい。

B.H.C. 水銀にあつては、600 時間後も接触毒、呼吸 毒作用放存して抢り、しろあり約 1 週間の間に全部 死亡した。

クロルデンも、B.H.C と同様に呼吸毒、接触毒作用 ともに残溜し、材も食害を全くうけていない。

水溶性の JIS K 1550 薬品の場合は 0，100特間己も に武験途折でラスコ内に名ニが登生したので測定が不
可能になつてしまつた。との薬戍は、食中毒作用存目的 としたもので木材在食害されるととにより効果の発揮が みられるのである。第 3 表に示すように 200 時間にお いては、軽微な食害と一部のしろありの死亡を確認して いる。ただし 400 時間在越せば而候操作をうけて薬剂が 溶出し效果がなくなつてしまう。

この結果よりいえしろあり被害地域におりる防ぎ処理 そは、クレオソート油単独での処理は效果がうすく、必 ず防ぎ剤と併用しなければならない。

\section{5. 結}

防ぎ工法研究の一環としで、建築用材、木質材料のし ろあり食害試験ならびに防ぎ剤の効力試験を実施した。

i 建贸用材は 25 樹種について試験を行なつたがそ のいずれも食書をうけ比重の大なるものほど食害が少な い傾向がある。乙の結果からでは、総体的に広葉樹の方 が針葉樹に比較して食害が少ない。なかでもチークはき わだつて食害が少なかつた。

ii 防ぎ剂の効力試験結果では、クロルデン、B.H.C. などが成績がよく、クレオソート油はウエザーメーター にかけた場合は、水洗法よりも老化が促進するものと思 われる。

iii 試験方法の検討としては、試験結果に非常にばら つきが多いことから再現性が危ぶまれる。樹種内の食害 率の偏差は相当あり、全樹種平均食害率偏差は土17\% あり、との偏差が少くなるやうな試験法在確立すること。 か望まれる。

[引用文献]

1) 日本建築学会諭文報告集第 60 号昭和 33 年 10 月，防蟻剂! の效力試験方法について 十代田, 神山, 肱黑 